\title{
Development and Interactions among Academic Performance, Word Recognition, Listening, and Reading Comprehension
}

\author{
Desenvolvimento e Interação entre Desempenho Escolar, Reconhecimento \\ de Palavras e Compreensão Auditiva e de Leitura
}

\author{
Natália Martins Dias*, ${ }^{*}$, José Maria Montiel ${ }^{a} \&$ Alessandra Gotuzo Seabra ${ }^{b}$ \\ ${ }^{a}$ Centro Universitário FIEO - UniFIEO - Fundação Instituto de Ensino para Osasco, Osasco, SP, Brasil \\ $\&{ }^{b}$ Universidade Presbiteriana Mackenzie, São Paulo, SP, Brasil
}

\begin{abstract}
This study investigated how the development of word recognition, listening and reading comprehension skills correlates with academic performance over the course of elementary school. The Contrastive Test of Listening and Reading Comprehension and the Words and Non-words Reading Competence Test were used to assess 301 Brazilian students attending the $1^{\text {st }}$ to $4^{\text {th }}$ grades of elementary education, whose academic performance records were provided by the school at the end of the year. Analysis shows a significant effect of grade level on all variables and a pattern of higher scores in items that can be read by logographic strategy and lower scores for items that need orthographic processing. Several significant correlations between measured skills and academic performance were found, though the pattern of these correlations shifted within different grade levels. There were stronger relations between academic performance and more elementary abilities, such as logographic strategy of reading and listening comprehension in the 1st grade, and with more complex skills developing during the next three grades, as shown by the increase of correlations with alphabetic and orthographic strategies and reading comprehension. These data can help guide practices that stimulate relevant skills in each school level.

Keywords: School learning, development, reading skills.

Resumo

Este estudo investigou como o desenvolvimento das habilidades de reconhecimento de palavras, compreensão auditiva e de leitura relaciona-se ao desempenho escolar ao longo do Ensino Fundamental I. O Teste Contrastivo de Compreensão Auditiva e de Leitura e o Teste de Reconhecimento de Palavras e Pseudopalavras foram utilizados na avaliação de 301 estudantes brasileiros da $1^{\mathrm{a}}$ à $4^{\mathrm{a}}$ série do Ensino Fundamental. As notas escolares foram fornecidas pela escola ao término do ano letivo. As análises revelaram efeito significativo da série sobre todas as variáveis e um padrão com escores mais elevados em itens que podem ser lidos pela estratégia logográfica e escores mais baixos para itens que demandam processamento ortográfico. Diversas correlações significativas entre as habilidades mensuradas e o desempenho escolar foram encontradas, porém o padrão destas correlações mudou nas diferentes séries escolares. Houve correlações mais fortes entre desempenho escolar e habilidades mais elementares, como a estratégia logográfica de leitura e a compreensão auditiva, na $1^{a}$ série, e com habilidades mais complexas desenvolvendo-se ao longo das três séries sucessivas, como evidente pelo aumento de correlações com as estratégias alfabética e ortográfica e com a compreensão de leitura. Os dados podem auxiliar a orientar práticas para estimular habilidades relevantes em cada nível escolar.
\end{abstract}

Palavras-chave: Aprendizagem escolar, desenvolvimento, habilidades de leitura.

This article adds a developmental perspective in the investigation of reading strategies, listening and reading comprehension, and their relations with academic performance. The reading strategies development curves and the developmental patterns of listening and reading

\footnotetext{
${ }^{*}$ Mailing address: Av. Franz Voegeli, 577, B1. 5, Apto. 6, Osasco, SP, Brasil 06020-190. Phone: +55 11 9818-7335.

E-mail: natalia.dias@unifieo.br
}

comprehension have been established, as well as the correlation between reading, comprehension abilities, and academic performance. What this study wants to add is the differential patterns of correlation between reading, comprehension abilities, and academic performance as a function of school grade. It could help to highlight which abilities tend to be more prominent or more crucial for academic performance in children at different grade levels. 
Dias, N. M., Montiel, J. M. \& Seabra, A. G. (2015). Development and Interactions among Academic Performance, Word Recognition, Listening, and Reading Comprehension.

In the following sections, we will present some Brazilian data about students' performance. Given this view, we agree that is essential to understand the potential relations between academic performance and other variables, including the ones involved in reading competence. Considering the Simple View of Reading, the last section of our introduction provides a review about strategies for word recognition, listening, and reading comprehension. In this sense, we are interested in how these components are related to school performance in different grade levels.

\section{Performance of Brazilian Children Attending Elementary School}

Academic performance has been the subject of multiple recent studies. Overall, as summarized by Araújo (2002), performance can be understood as the result of multiple interactions between several factors, including school characteristics, physical and pedagogic aspects, teacher qualifications, family attributes like parental style and education level, and individual characteristics such as physical health, motivation to learn, emotional factors and cognitive development.

In Brazil, elementary school students' performance scores in Portuguese language and mathematics were well below expected levels, according to the official expectations of the Education Ministry. For example, in Prova Brasil, a national survey conducted biannually in the country, students attending $4^{\text {th }}$ grade in elementary school had an average performance of 172 test points in Portuguese on a scale ranging from 0 to 500 points, in which the minimum expected performance was 250 points (Ministério da Educação, 2005; J. B. Oliveira \& Schwartzman, 2002).

The results of the Program for International Student Assessment (PISA), released by the Organization for Economic Cooperation and Development (OECD), confirmed the national data. In PISA, Brazilian students were classified in the $53^{\text {rd }}$ position in the math test (of 57 countries) and $48^{\text {th }}$ in the reading test (of 56 countries; Gois \& Pinho, 2007). In the most recent report of PISA, Brazilian students maintained their poor performance and were classified in the $57^{\text {th }}$ position in the math test (of 65 countries) and $53^{\text {rd }}$ in the reading test (of 65 countries). Latin-American countries like Argentina, Mexico, Peru, Panama, Chile and Colombia also reported performance scores significantly below the OECD average (OECD, 2010).

Faced with such evidence, it becomes essential to understand the potential relations between academic performance and other factors. School performance is potentially influenced by several factors; this multifaceted conception of performance is supported by empirical corroboration from diverse research fields, including the investigation of cognitive abilities, cognitive and metacognitive strategies, motivation and meaning of the school learning, mental health, gender, homework routine, mothers' educational level, and readiness (Blatchford, Burke, Farquhar, Plewis, \& Tizard, 1985; Boruchovitch, 1999; A. G. S. Capovilla \& Dias, 2008; Capellini, Tonelotto,
\& Ciasca, 2004; Dell'Aglio \& Hutz, 2004; Duncan et al., 2007; Holmes \& Croll, 1989; Pastura, Mattos, \& Araújo, 2005; Valenzuela, 2008).

\section{What Variables are Related with Academic Performance?}

The academic performance measures used in the mentioned studies and the factors being investigated in relation to them have been diverse. For example, Dell'Aglio and Hutz (2004) used an Educational Achievement Assessment Scale to find a negative correlation with depressive symptoms, suggesting that children and adolescents with a higher incidence or severity of depressive symptoms tend to have poorer academic performances. Capellini et al. (2004) used the School Performance Test (SPT) as a measure of $2^{\text {nd }}$ to $4^{\text {th }}$ grade students' performance, comparing it with teachers' perspectives. They found that children classified by teachers as having learning difficulties formed the group with scores below average in reading, writing and arithmetic activities as assessed by SPT. The study emphasizes the importance of the teacher's role in identifying school difficulties and problems.

Another measure that can be used to assess school performance is the scholar mark or grade that reflects a fairly ecological assessment. Capovilla and Dias (2008) found that annual scholar marks are significantly correlated with attention, mainly divided attention. The authors hypothesized that this attentional skill plays an important role in the classroom and it is demonstrated, for example, when a child takes note of the blackboard while simultaneously attempting to pay attention to the teacher's explanations. These results are consistent with the findings of Pastura et al.'s review (2005), which concluded poor school performance is related to the presence of attentional compromise, as observed in Attention Deficit Hyperactivity Disorder (ADHD), mainly the inattentive type.

Other studies have also contributed to research in this area. In general, they have provided some evidence that academic performance is not related to ethnicity but is related to gender, with girls attaining the best performances, though this finding was tied to parental support at home and the mothers' educational level (Blatchford et al., 1985). Time spent on homework was also a variable strongly related to academic performance (Holmes \& Croll, 1989).

Considering cognitive factors that may relate to school performance, Boruchovitch (1999) provides a review of studies that attest to the close correlation between learning strategies and academic performance. These cognitive strategies include the ability to monitor behavior and to exercise self-regulation during the learning process. A meta-analysis conducted by Duncan et al. (2007) showed that the mathematical, reading and attentional skills assessed at the beginning of schooling, in this order, were the best predictors of later academic performance, while other factors such as socioeconomic level, gender and social and emotional aspects did not contribute as significantly to predicting performance. Contributing to this line of research, 
addressing specifically to the cognitive processes involved in reading, our study investigated the potential relations among academic performance, isolated word-recognition skills, and listening and reading comprehension.

\section{Reading Competence: Strategies for Word Recognition and Comprehension}

The dual skills of word recognition and listening comprehension are recognized in the literature as the main components of reading competence, according to the Simple View of Reading (SVR; Aaron, Joshi, Gooden, \& Bentum, 2008; Aaron, Joshi, \& Williams, 1999; Betjemann et al., 2008; Gough \& Tunmer, 1986). Although evidence supports this model, studies have also suggested that other skills may be integrated into the reading competency model, such as processing speed or fluency in word recognition (Aaron et al., 2008; Aaron et al., 1999; Oakhill, Cain, \& Bryant, 2003; Tilstra, McMaster, Van den Broek, Kendeou, \& Rapp, 2009).

Comprehension is the ultimate goal of competent reading, and many of the components involved in reading comprehension are not unique for written language. That is, they are also used to understand spoken language, as listening or linguistic comprehension (Kershaw \& Schatschneider, 2010). On contrary, word recognition remains a specific component of the reading processes. Evidence suggests that reading comprehension and word recognition share certain common processing components but also make their own unique cognitive demands (Seabra \& Dias, 2012).

Word recognition can occur by different strategies. The first of these strategies is characterized by the use of contextual cues in reading, with the child interpreting words as drawings and reading for overall visual recognition. This strategy is called logographic. As formal schooling begins, the child learns correspondence rules between letters and phonemes and starts to use these processes in reading and writing. This is the alphabetic strategy, and its use allows the subject to convert writing into sound to enable reading of new words and non-words. Finally, due to their accumulated reading experiences, readers constitute a mental orthographic lexicon, becoming able to read familiar words using the orthographic strategy or through direct recognition without resorting to phonological conversion (Frith, 1985, 1997).

These strategies are developed as school progresses, from a predominantly logographic stage at $1^{\text {st }}$ grade to an alphabetic reading in the $2^{\text {nd }}$ and $3^{\text {rd }}$ grades that shifts to an increasing use of orthographic strategies in the $3^{\text {rd }}$ and $4^{\text {th }}$ grades (Capovilla \& Dias, 2007; Diuk, Borzone, Abchi, \& Ferroni, 2009; Salles \& Parente, 2002). Additionally, reading comprehension, a more complex ability that integrates other cognitive processes (Marmolejo-Ramos, 2007), has shown a progressive developmental curve from the $1^{\text {st }}$ to the $4^{\text {th }}$ grade (Suehiro 2008). From a developmental perspective, the evidence also suggests that the relative importance of word-recognition skills and listening comprehension for reading comprehension appears to shift as school progresses. That is, the role of word-recognition skills for reading comprehension tends to decrease as children advance in school levels, whereas the importance of listening comprehension tends to increase (Oakhill et al., 2003; Tilstra et al., 2009).

Indeed, a recent meta-analysis corroborates this data, at least for English, suggesting a different pattern of relations between the SVR components in the course of early reading development. For example, in the English language, decoding is a better predictor of reading comprehension in children with one to two years of reading instruction, whereas listening comprehension is a better predictor of reading competence in children with three to five years of reading instruction. In addition, the type of decoding skills (accuracy in words, non-words or fluency) more related with reading comprehension changes in the course of schooling, which can mean that different abilities are emerging in this period. However, the study also revealed that different types of orthography could affect the relations between SVR components. Therefore, considering more transparent orthographies, in which the relations between letters and sounds tend to be regular, listening comprehension is more important than decoding for reading competence from the very early stages of reading acquisition (Florit \& Cain, 2011). Considering that the Portuguese language has a more transparent orthography than English does, probably this pattern is also valid to Portuguese.

Research has been also conducted to elucidate the relation between reading skills and school performance (e. g., Oliveira, Boruchovitch, \& Santos, 2008; Tonelotto et al., 2005). One of these studies found that performance assessed by SPT was associated with percentage hit and reaction time in a reading test of words and non-words in a sample of children 8 to 11 years old. Children who demonstrated superior performance in the SPT had a higher percentage hit and shorter reaction time in the reading of words than non-words (Tonelotto et al., 2005), which suggests that the orthographic strategy was more strongly related to academic performance than the alphabetical strategy. A relation between reading comprehension and academic performance, as assessed by the Portuguese language and mathematics school marks, was found in children from $5^{\text {th }}$ to $8^{\text {th }}$ grades. For the authors, this relation suggests the importance of reading comprehension when learning different types of school content (Oliveira et al., 2008).

The results confirm that reading skills (such as word recognition and reading comprehension) relate to academic performance. By extension, they also support the idea that reading is an essential tool for self-education, providing access to a wealth of information (Lukasova, 2006). Nevertheless, it is not clear which of these skills would dominate in performances at different school levels. As the developmental studies illustrate (e.g., A. G. S. Capovilla \& Dias, 2007; Diuk et al., 2009; Florit \& Cain, 2011; Oakhill et al., 2003; Salles \& Parente, 2002; Tilstra et al., 2009), reading patterns change over school years, and it is likely 
Dias, N. M., Montiel, J. M. \& Seabra, A. G. (2015). Development and Interactions among Academic Performance, Word Recognition, Listening, and Reading Comprehension.

that, at the different education levels, different reading skills play differential roles in students' performance.

This study aimed to investigate the development of listening and reading comprehension and word recognition through logographic, alphabetic and orthographic strategies. It also aimed to explore the relation between these skills and school performance in $1^{\text {st }}$ to $4^{\text {th }}$ grade children attending elementary school, taking a developmental perspective. We chose this grade range because it is the period for development of literacy skills in Brazil. We expected that, during these successive school years, listening and reading comprehension and word recognition establish differential relational patterns with academic performance. More specifically, listening comprehension probably has a consistent relation with academic performance in the early grades, mainly the $1^{\text {st }}$ grade, and reading comprehension should assume greater relations with academic performance from $2^{\text {nd }}$ or $3^{\text {rd }}$ grades, because reading comprehension includes a charge of both, listening comprehension and word-recognition skills. Regarding word-recognition strategies, we expect that the pattern of relations with academic performance changes as different skills emerge; that is, the pattern of relations will change with the development of alphabetic and orthographic strategies and their increasing use and importance for children's performance in the course of the schooling.

Hence, these results may contribute to understand skills prevalent or relevant to performance at each grade level, which is useful information for teachers who work directly with children in these development stages. This is the first Brazilian and Latin-American study to investigate the relations between those abilities from a developmental perspective. Given that Florit and Cain (2011) argue that there are few investigations in languages other than English, it is important to supply data from Brazilian children (Portuguese language).

\section{Method}

\section{Participants}

The final sample included 301 children of both genders (48.8\% males) attending the $1^{\text {st }}$ to $4^{\text {th }}$ grades of elementary public school in a city in the state of São Paulo, Brazil, with a mean age of 103 months $(S D=13.90)$. Out of this total, 70 students ( $60 \%$ males) attended $1^{\text {st }}$ grade ( $M=84$ months, $S D=3.70), 89(52.8 \%$ males $)$ attended $2^{\text {nd }}$ grade $(M=98$, $S D=4.31), 64(45.3 \%$ males $)$ attended $3^{\text {rd }}$ grade $(M=108$; $S D=4.24)$ and $78(37.2 \%$ males $)$ attended $4^{\text {th }}$ grade $(M=$ $121, S D=4.15)$. To create this final sample $(N=301)$ we chose to exclude children with an age-grade discrepancy by adopting the following correspondence: $1^{\text {st }}$ grade -6 and 7 years; $2^{\text {nd }}$ grade -7 and 8 years; $3^{\text {rd }}$ grade -8 and 9 years; $4^{\text {th }}$ grade -9 and 10 years. Children who did not fit these criteria were excluded from the sample. Among the participants, there were no students with known, uncorrected mental or sensory disabilities. Students at this school came from low and medium-low socioeconomic status homes, according to data obtained as general information about the school population and neighbourhood.

\section{Materials}

Words and Non-words Reading Competence Test (WNw-RCT). The WNw-RCT (Seabra \& Capovilla, 2010) assesses competence in reading isolated words and is comprised of 70 test items, each of which features a picture paired with a written word. There are seven different kinds of items (10 items of each kind). Figure 1 presents an example of each kind of item. The items of correct regular and irregular words should be accepted and those with semantic errors or non-words must be rejected.
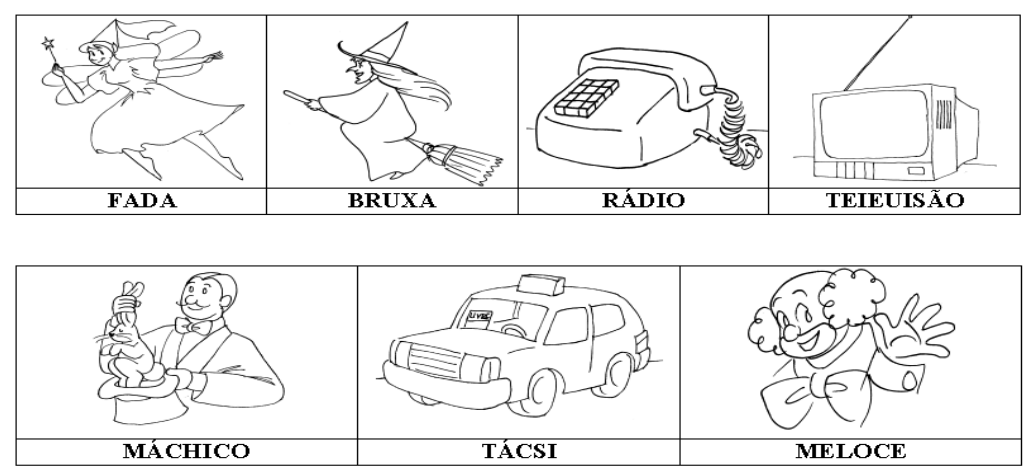

Figure 1. Examples of items of the WNw-RCT. In order of the presentation: Correct regular words $(\mathrm{CR})$ - the word ' $F A D A$ ' (fairy) on the figure of a fairy; correct irregular words (CI) - the word ' $B R U X A$ ' (witch) on the figure of a witch; semantic changes (SC) - the word ' $R A$ 'DIO' (radio) on the picture of a phone; visual changes (VC) - the word 'TEIEUISÃO' (a visual distortion) on the figure of a television; phonological changes (PC) - the word 'MÁCHICO' (with a wrong sound) on the figure of magic; homophone non-words $(\mathrm{HN})$ - the word 'TACSI' (a non-word with the same sound than TAXI) on the figure of a taxi; and weird non-words $(\mathrm{WN})$ - the word 'MELOCE' (a word that does not exist) on the figure of a clown. 
The distribution pattern of error types can indicate the reading strategies used. For example, items with correct regular words [CR, e.g., the word ' $F A D A$ ' (fairy in English) on the figure of a fairy], semantic changes [SC,

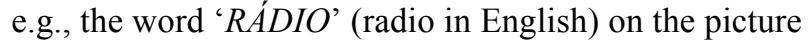
of a phone] and weird non-words [WN, e.g., the word 'MELOCE' (a word that does not exist in Portuguese) on the figure of a clown] can be read correctly by any of the three reading strategies. Conversely, the visual changes [VC, e.g., the word 'TEIEUISÃO' (the correct way to write it in Portuguese is TELEVISÃO) on the figure of a television] and the phonological changes [PC, e.g., the word 'MÁCHICO' (the correct way to write it in Portuguese is $M A ́ G I C O$ ) on the figure of magic] cannot be read by the logographic strategy, but only by the alphabetical and orthographic strategies, because, although they possess a similar visual structure to the correct word, they must be rejected. Therefore, errors in these items suggest the absence of alphabetic and orthographic reading strategies.

The correct irregular words [CI, e.g., the word 'BRUXA' (witch) on the figure of a witch] can be read by the logographic or the orthographic strategy, but not by the alphabetic, as in this case the application of graphophonemic correspondence rules leads to settlement mistakes and words tend to be rejected. Finally, the homophone non-words [HN, e.g., the word 'TACSI' (the correct way to write is TAXI) on the figure of a taxi] can only be correctly read using the orthographic strategy because if other reading strategies are relied upon, the word would be accepted, as it looks and sounds similar to the correct word. Thus, HN errors suggest an absence of the orthographic strategy. Hence, the pattern of responses may help identify the particular nature of a child's reading difficulty. Seabra and Capovilla (2010) reported reliability indices $(\alpha=.92)$, validity evidence (school grade effects, correlation with other variables), and normative data ( $1^{\text {st }}$ to $4^{\text {th }}$ grades) on the $\mathrm{WNw}-\mathrm{RCT}$. The scores computed for the WNw-RCT were the correct answers (i.e., correct regular and irregular words accepted and semantic errors or non-words rejected). For analysis, we used the mean score in each kind of item and in the total test (0-1).

Contrastive Test of Listening and Reading Comprehension (CTLRC). The CTLRC (Capovilla \& Seabra, 2013) assesses listening and reading comprehension skills. The comparison between the two skills enables the differential diagnosis of reading acquisition disorder, differentiating it from general language disturbance. The instrument consists of two subtests: Reading Comprehension (RC) and Listening Comprehension (LC), each with 40 test items arranged in order of increasing difficulty. Figure 2 presents an example of each subtest. For each item, the child must choose between five alternative figures, the one that corresponds to the sentence heard in the case of the LC subtest or read in the case of the RC. Seabra, Dias, and Capovilla (2013) presented reliability indices $(\alpha \geq .86$ to $\mathrm{LC}$, and $\alpha \geq .97$ to RC), validity evidence (school grade effects, correlation with other variables), and normative data (6 to 11 years old) on the CTLRC. The scores computed for the CTLRC were the correct answers. For analysis, we used the total score in each part of the test $(0-40)$.
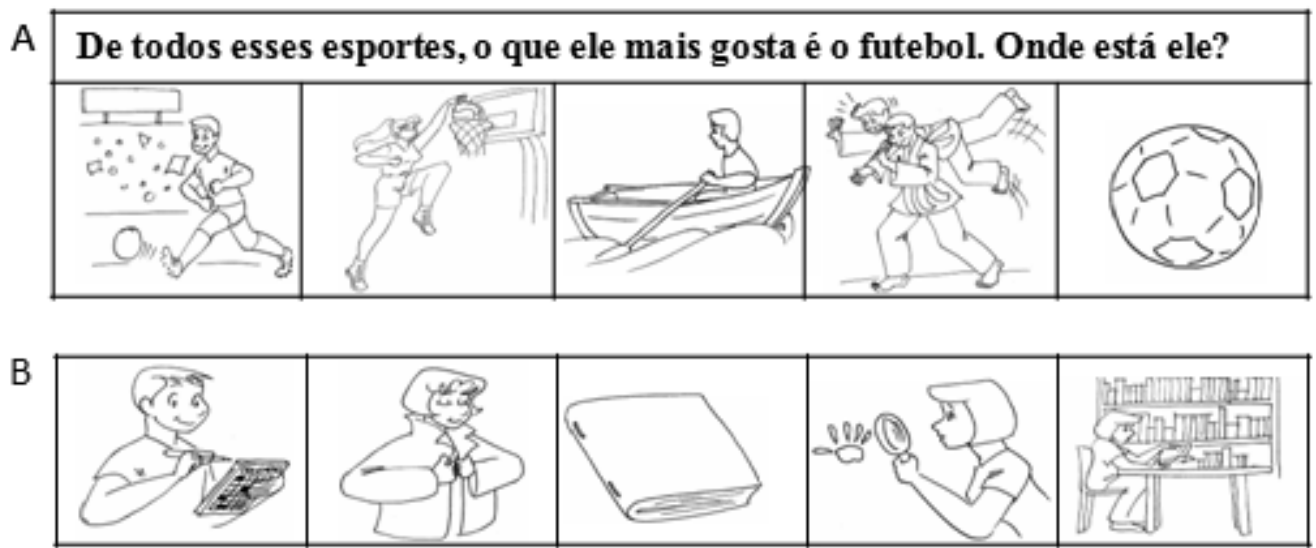

Figure 2. Examples of items from Reading Comprehension (A) and Listening Comprehension (B) subtests of the CTLRC. In A, the sentence to be read is "Of all these sports, what he likes most is soccer. Where is it?" In B, the sentence to be listened is "The woman is studying in the library".

School Performance. The participating school uses a scoring system including grades from 0 to 10 , with periodic assessments every two months for a total of four grades for each subject during one school year. In this study we used an overall average of grades in Portuguese, Mathematics, Science, Geography and History disciplines, calculated based on grades for the entire school year.

\section{Procedure}

Our study was approved by the Research Ethics Committee. An Agreement Term was sent to the students' 
Dias, N. M., Montiel, J. M. \& Seabra, A. G. (2015). Development and Interactions among Academic Performance, Word Recognition, Listening, and Reading Comprehension.

parents, asking for their consent to carry out the research. The instruments were collectively applied in the classroom in three sessions, one for the WNw-RCT and one for each CTLRC subtest (Reading and Listening Comprehension), allowing for a one-week interval between tests. The assessment sessions lasted approximately 30 minutes each. The assessment occurred in the middle of the school year. School performance data (grades) were provided by the school board at the end of the school year.

\section{Results}

The CTLRC and WNw-RCT descriptive statistics are presented in Table 1. As shown in the normative data (Seabra \& Capovilla, 2010; Seabra et al., 2013), participants' average scores in all grades and tests were concentrated in the normal range of the standard score (i.e., in the limit of a standard deviation below and above the mean), suggesting that the sample is representative of the normative population.

Table 1

Descriptive and Inferential Statistics Obtained After MANOVAs of the Effect of Grade Levels on the Performances on CTLRC, WNw-RCT, and School Marks Average (Standard Deviation in Parentheses), as a Function of School Grade

\begin{tabular}{|c|c|c|c|c|c|c|c|c|}
\hline \multirow{2}{*}{$\begin{array}{l}\text { Test/ } \\
\text { subtests }\end{array}$} & \multicolumn{6}{|c|}{ School Grade } & \multirow{2}{*}{$\begin{array}{c}\text { Partial Eta } \\
\text { Squared }\end{array}$} & \multirow{2}{*}{$\begin{array}{c}\text { Bonferron } \\
\text { analysis }\end{array}$} \\
\hline & $1^{\text {st }}$ & $2^{\text {nd }}$ & $3^{\text {rd }}$ & $4^{\text {th }}$ & $F$ & $p$ & & \\
\hline CTLRC-RC & $8.64(5.88)$ & $27.34(9.93)$ & $35.64(3.57)$ & $36.86(3.74)$ & $F(3,301)=274.78$ & $<.01$ & .74 & $1<2<3,4$ \\
\hline CTLRC-LC & $31.27(5.80)$ & $34.98(4.64)$ & $37.97(1.76)$ & $38.18(2.26)$ & $F(3,301)=45.78$ & $<.01$ & .32 & $1<2<3,4$ \\
\hline WNw-RCT & $.68(.11)$ & $.83(.08)$ & $.89(.06)$ & $.93(.07)$ & $F(3,301)=122.43$ & $<.01$ & .55 & $1<2<3,4$ \\
\hline $\mathrm{WN}$ & $.90(.19)$ & $.97(.07)$ & $.99(.04)$ & $.99(.06)$ & $F(3,301)=10.01$ & $<.01$ & .09 & $1<2,3,4$ \\
\hline $\mathrm{SC}$ & $.87(.18)$ & $.95(.10)$ & $.93(.09)$ & $.95(.09)$ & $F(3,301)=7.63$ & $<.01$ & .07 & $1<2,3,4$ \\
\hline $\mathrm{CR}$ & $.67(.22)$ & $.88(.10)$ & $.95(.08)$ & $.95(.09)$ & $F(3,301)=69.46$ & $<.01$ & .41 & $1<2<3,4$ \\
\hline $\mathrm{VC}$ & $.64(.22)$ & $.89(.14)$ & $.91(.09)$ & $.93(.11)$ & $F(3,301)=59.77$ & $<.01$ & .38 & $1<2,3,4$ \\
\hline $\mathrm{PC}$ & $.63(.22)$ & $.77(.20)$ & $.88(.17)$ & $.92(.15)$ & $F(3,301)=33.60$ & $<.01$ & .25 & $1<2<3,4$ \\
\hline $\mathrm{HN}$ & $.57(.23)$ & $.56(.24)$ & $.69(.23)$ & $.84(.18)$ & $F(3,301)=26.89$ & $<.01$ & .21 & $1,2<3<4$ \\
\hline CI & $.47(.22)$ & $.75(.17)$ & $.88(.12)$ & $.91(.11)$ & $F(3,301)=106.64$ & $<.01$ & .55 & $1<2<3,4$ \\
\hline $\begin{array}{l}\text { School } \\
\text { Marks }\end{array}$ & $7.13(2.08)$ & $6.46(2.10)$ & $6.21(1.56)$ & $6.51(1.78)$ & -- & -- & -- & -- \\
\hline
\end{tabular}

Note. CTLRC-RC - Contrastive Test of Listening and Reading Comprehension - Reading Comprehension; CTLRC-LC - Contrastive Test of Listening and Reading Comprehension - Listening Comprehension; WNw-RCT - Words and Non-words Reading Competence Test; WN - weird non-words; SC - semantic changes; CR - correct regular words; VC - visual changes; PC - phonological changes; $\mathrm{HN}$ - homophones non-words; $\mathrm{CI}$ - correct irregular words.

Table 1 also presents the MANOVA results of school grade effects on CTLRC and WNw-RCT, as well as Bonferroni post hoc comparison. We observed significant increasing performance in all measures as grade level increased. Both listening and reading comprehension scores increased from $1^{\text {st }}$ to $2^{\text {nd }}$ and, then, $2^{\text {nd }}$ to $3^{\text {rd }}$ grade. Nonsignificant differences were observed only between the $3^{\text {rd }}$ and $4^{\text {th }}$ grades. The WNw-RCT overall average had a progressive increase from $1^{\text {st }}$ to $2^{\text {nd }}$ to $3^{\text {rd }}$ grade. The $3^{\text {rd }}$ and $4^{\text {th }}$ school levels, again, showed no significant differences. In terms of WNw-RCT subtests, $1^{\text {st }}$ grade performed poorly than other grades in $\mathrm{WN}, \mathrm{SC}$ and VC subtests. In CR, PC and $\mathrm{CI}$ subtests, increasing performance was observed over the school years, except between the $3^{\text {rd }}$ and $4^{\text {th }}$ grades. In $\mathrm{HN}$, the $1^{\text {st }}$ and $2^{\text {nd }}$ grades were not differentiated, but as the school level progressed, the differences became significant, with the final series achieving the best performance.
For WNw-RCT subtests scores, repeated measures ANOVA was conducted with grade as the between-subjects factor and the subtests as within-subjects variable. A significant effect of grade, $F(3,297)=122.43 ; p \leq .001$; Partial Eta Squared $=.55$, subtest, $F(6,1782)=147.31$; $p \leq .001$; Partial Eta Squared $=.33$, and grade $\mathrm{X}$ subtest interaction were found, $F(18,1782)=17.06 ; p \leq .001$; Partial Eta Squared $=.15$. To compare the performance in each subtest within each grade, repeated measures ANOVAs were individually conducted for each grade level, and results are shown in Table 2. Generally, in all grades, the most consistent findings were scores on $\mathrm{WN}$ and SC items, that were significantly higher than all the others (there was only one exception, the absence of significant differences between $\mathrm{WN}$ and $\mathrm{SC}$ in $2^{\text {nd }}$ grade), and $\mathrm{HN}$ scores, that were significantly lower than all the others were (except for $\mathrm{CI}$ in the $1^{\text {st }}$ grade). 
Psicologia: Reflexão e Crítica, 28(2), 404-415.

Table 2

Post-hoc Comparisons (LSD) Obtained After Repeated Measures ANOVA of the Effect of Subtest on the Performances on WNw-RCT Subtests for Each Grade Level

\begin{tabular}{lcc}
\hline Grades & $p$ & Significant differences \\
\hline $1^{\text {st }}$ grade & $<.01$ & $\mathrm{WN}>\mathrm{SC}>\mathrm{CR}, \mathrm{VC}, \mathrm{PC}>\mathrm{CI}>\mathrm{HN}$ \\
$2^{\text {nd }}$ grade & $\mathrm{WN}=\mathrm{SC}>\mathrm{CR}, \mathrm{VC}>\mathrm{PC}, \mathrm{CI}>\mathrm{HN}$ \\
$3^{\text {rd }}$ grade & $\mathrm{WN}>\mathrm{SC}, \mathrm{CR}>\mathrm{VC}, \mathrm{PC}, \mathrm{CI}>\mathrm{HN}($ except SC $=\mathrm{VC})$ \\
$4^{\text {th }}$ grade & $<.01$ & $\mathrm{WN}>\mathrm{SC}, \mathrm{CR}, \mathrm{VC}, \mathrm{PC}>\mathrm{CI}>\mathrm{HN}($ except CI $=\mathrm{VC}, \mathrm{PC})$ \\
\hline
\end{tabular}

Another aim of this study was to investigate the relations among: (a) listening and reading comprehension, (b) word-recognition skills and (c) school performance, which is represented here by average grades (school marks) in
Portuguese (includes grades for Language Arts), Mathematics, Science, History and Geography disciplines at the end of the school year. Table 3 presents the correlation matrix to each grade level.

Table 3

Correlation Matrix, With Pearson's Correlation Coefficients and Significance, Between School Performance and the Scores on the CTLRC and WNw-RCT in Each Grade Level

\begin{tabular}{|c|c|c|c|c|c|}
\hline \multirow{2}{*}{ Test/Subtest } & & \multicolumn{4}{|c|}{ School Performance } \\
\hline & & $1^{\text {st }}$ Grade & $2^{\text {nd }}$ Grade & $3^{\text {rd }}$ Grade & $4^{\text {th }}$ Grade \\
\hline \multirow[t]{2}{*}{ CTLRC-RC } & $r$ & .33 & .73 & .44 & .52 \\
\hline & $p$ & .005 & $<.001$ & $<.001$ & $<.001$ \\
\hline \multirow[t]{2}{*}{ CTLRC-LC } & $r$ & .57 & .43 & .32 & .47 \\
\hline & $p$ & $<.001$ & $<.001$ & .011 & $<.001$ \\
\hline \multirow[t]{2}{*}{ WNw-RCT } & $r$ & .64 & .56 & .41 & .36 \\
\hline & $p$ & $<.001$ & $<.001$ & .001 & .001 \\
\hline \multirow[t]{2}{*}{ WN } & $r$ & .46 & .14 & .09 & -.03 \\
\hline & $p$ & $<.001$ & .190 & .464 & .785 \\
\hline \multirow[t]{2}{*}{$\mathrm{SC}$} & $r$ & .50 & -.12 & -.01 & .003 \\
\hline & $p$ & $<.001$ & .273 & .944 & .979 \\
\hline \multirow[t]{2}{*}{$\mathrm{CR}$} & $r$ & .52 & .14 & .09 & .15 \\
\hline & $p$ & $<.001$ & .182 & .465 & .183 \\
\hline \multirow[t]{2}{*}{$\mathrm{VC}$} & $r$ & .27 & .43 & .12 & .30 \\
\hline & $p$ & .022 & $<.001$ & .362 & .008 \\
\hline \multirow[t]{2}{*}{$\mathrm{PC}$} & $r$ & .31 & .36 & .26 & .20 \\
\hline & $p$ & .010 & .001 & .037 & .082 \\
\hline \multirow[t]{2}{*}{$\mathrm{HN}$} & $r$ & -.07 & .43 & .42 & .50 \\
\hline & $p$ & .575 & $<.001$ & $<.001$ & $<.001$ \\
\hline \multirow[t]{2}{*}{ CI } & $r$ & .42 & .38 & .11 & .12 \\
\hline & $p$ & $<.001$ & $<.001$ & .371 & .281 \\
\hline
\end{tabular}


Dias, N. M., Montiel, J. M. \& Seabra, A. G. (2015). Development and Interactions among Academic Performance, Word Recognition, Listening, and Reading Comprehension.

Several significant correlations were found between reading skills and school performance. At the $1^{\text {st }}$ grade level, performance showed stronger correlations with the general measures of word recognition, listening comprehension and the $\mathrm{CR}, \mathrm{SC}, \mathrm{WN}$ and $\mathrm{CI}$ items of WNw-RCT, respectively, all with moderate coefficients. The correlations were low but significant with reading comprehension and with the PC and VC items of WNw-RCT, but showed no correlation with the HN item. That is, at this grade level, word recognition, listening skills, particularly $\mathrm{CR}, \mathrm{SC}, \mathrm{WN}$ and CI (logographic strategy), are more closely related to academic performance. Although significant, the correlations were too low to mean that reading comprehension or alphabetic strategy (VC, PC) still appear to have great importance in these students' performance. The lack of correlation with $\mathrm{HN}$ shows that the orthographic strategy, which is not yet developed at this school level, does not have any relevance to performance at $1^{\text {st }}$ grade.

A change in this pattern is observed at the $2^{\text {nd }}$ grade. A high correlation was found between school performance and reading comprehension measure, followed by moderate correlations, all of which were significant, with an overall mean of word-recognition assessment, listening comprehension and the $\mathrm{VC}, \mathrm{HN}, \mathrm{CI}$ and $\mathrm{PC}$ items of WNw-RCT. Correlations with the WN, SC and CR items of WNw-RCT were void. That is, at this school level, reading comprehension is the ability most strongly related to academic performance. The pattern of correlations with WNw-RCT items suggests that the logographic strategy
(WN, SC, CR) has become less important in academic performance, while the alphabetic and orthographic strategies (VC, HN, CI and PC) were more related to this performance.

At $3^{\text {rd }}$ grade, the highest correlation remained between school performance and reading comprehension, though moderate correlations were also found with the $\mathrm{HN}$ item of WNw-RCT and the general average of word recognition, and lower correlations were found with listening and the PC item of WNw-RCT. Reading comprehension and recognition by orthographic strategy and, at a lesser degree, the alphabetic strategy were most strongly related to academic performance in these students. A very similar pattern was found at the $4^{\text {th }}$ grade, in which, again, reading comprehension and the HN item of WNw-RCT demonstrated the highest correlation with school performance. Other significant correlations were those with listening comprehension and the overall average for word recognition and the $\mathrm{VC}$ items of $\mathrm{WNw}-\mathrm{RCT}$.

To explore these results controlling for the common variance between the three variables (word recognition, listening and reading comprehension), we conducted a partial correlation between total performance in the tests and school performance, again within each grade level. Only total scores were used in this analysis. Table 4 presents the partial correlation matrix. Some results corroborate previous analysis, but also some correlations were not significant after controlling for the common variance.

Table 4

Partial Correlation Matrix, With Pearson's Correlation Coefficients and Significance, Between School Performance and the Scores on the CTLRC and WNw-RCT in Each Grade Level

\begin{tabular}{|c|c|c|c|c|c|}
\hline \multirow{2}{*}{ Test/Subtest } & & \multicolumn{4}{|c|}{ School Performance } \\
\hline & & $1^{\text {st }}$ Grade & $2^{\text {nd }}$ Grade & $3^{\text {rd }}$ Grade & $4^{\text {th }}$ Grade \\
\hline \multirow{2}{*}{$\begin{array}{l}\text { CTLRC-RC } \\
\text { (controlling for CTLRC-LC } \\
\text { and WNw-RCT) }\end{array}$} & $r$ & .27 & .58 & .22 & .31 \\
\hline & $p$ & .029 & $<.001$ & .081 & .006 \\
\hline \multirow{2}{*}{$\begin{array}{l}\text { CTLRC-LC } \\
\text { (controlling for CTLRC-RC } \\
\text { and WNw-RCT) }\end{array}$} & $r$ & .36 & .011 & .022 & .25 \\
\hline & $p$ & .002 & .919 & .862 & .033 \\
\hline \multirow{2}{*}{$\begin{array}{l}\text { WNw-RCT } \\
\text { (controlling for CTLRC-RC } \\
\text { and CTLRC-LC) }\end{array}$} & $r$ & .50 & .32 & .24 & .11 \\
\hline & $p$ & $<.001$ & .002 & .063 & .335 \\
\hline
\end{tabular}

At the $1^{\text {st }}$ grade level, performance showed stronger correlation with word recognition. The correlations were low but significant with listening and reading comprehension. At this grade level, even controlling for common variance, word recognition is more closely related to academic performance. However, listening, followed by reading comprehension, also appear to have some importance in these students' performance.

At the $2^{\text {nd }}$ grade, a moderate correlation was found between school performance and the reading-comprehension measure and a low, but significant one, was found between school performance and word recognition. Con- 
trolling for the common variance, the correlation between school performance and listening comprehension was no longer significant. For $3^{\text {rd }}$ grade, correlations between school performance and the tests measures were not significant after controlling for common variance. Only marginally significant correlations were found between school performance and word recognition, and reading comprehension, a pattern similar to that of $2^{\text {nd }}$ grade. At $4^{\text {th }}$ grade, low but significant correlations were evident between school performance and reading and listening comprehension. The relation with word recognition was not significant after controlling for common variance in this grade level.

\section{Discussion}

The findings from ANOVA of grade effect on CTLRC and $\mathrm{WNw}-\mathrm{RCT}$ scores are consistent with previous research. Suehiro (2008) has already demonstrated that reading comprehension ability develops from $1^{\text {st }}$ to $4^{\text {th }}$ grade. These results confirm and expand this statement, also investigating listening comprehension and wordrecognition development. Listening, like reading, also follows a developmental curve until the $3^{\text {rd }}$ and $4^{\text {th }}$ grades; interestingly, reading comprehension tended to approach listening comprehension performance along with grade level progression, suggesting that at the final grades of the first cycle of elementary education, children would be able to understand a text just as well when they read it as when they heard it, what is in line with findings of the SVR, that is, performance on reading and listening comprehension becomes more and more similar as word recognition develops and is consolidated (Aaron et al., 2008; Gough \& Tunmer, 1986).

The school grade effect on WNw-RCT subtests suggests scores on items that can be read by alphabetic or logographic strategies have increased between the initial grades, while scores on $\mathrm{HN}$ items, which can only be read by the orthographic strategy, only differ in the final grades. This pattern makes sense given theoretical models, which suggest further development of alphabetical and logographic strategy in early literacy and further development of orthographic processing in more advanced grades (A. G. S. Capovilla \& Dias, 2007; Diuk et al., 2009; Salles \& Parente, 2002).

Despite growth in all word-recognition strategies, a pattern was observed in all grades: the WNw-RCT subtests analysis revealed that items that can be read logographically are the easiest in all school grades, while the ones that need orthographic reading are the most difficult in all grades. That is, despite the development of orthographic strategy in more advanced grades, this reading strategy has not reached yet the same level of proficiency of other strategies, especially of logographic, reflected in lower scores on the items that must be read by orthographic strategy. The alphabetic strategy presented intermediate difficulty (i.e., items that require this strategy were not the easiest neither the most difficult). Thus, in the school grade range measured, the development of orthographic strategy was not enough to allow a performance similar to other strategies, and the development of alphabetic strategy seems to allow intermediate performance.

Concerning the correlation analysis, several significant correlations were found between listening and reading skills and school performance. Indeed, Oliveira et al. (2008) and Tonelotto et al. (2005) have shown that both the skills of word recognition and reading comprehension are related to academic performance. Duncan et al. (2007) also showed that reading skills are good predictors of later school performance. This finding, observed in English language (opaque orthography), was also observed in this study in Portuguese language (more transparent orthography), supporting the importance of word recognition and reading comprehension to academic performance across languages. However, as had been previously hypothesized, the relations among the variables change over the course of $1^{\text {st }}$ to $4^{\text {th }}$ grade. Thus, most interesting information can be obtained by paying attention to the pattern of correlations and to the change of this pattern in successive school levels, which can indicate that different skills would have greater relative importance for school performance in different school grade levels.

In line with our previous hypothesis, these results suggest that $1^{\text {st }}$ grade students with good listening comprehension skills or that use the logographic strategy tend to have good academic performances. Thus, according to Florit and Cain (2011), listening comprehension is an important ability since the very early stages of literacy, as expected for transparent orthographies. Reading via alphabetic strategy has hardly begun in this grade, but it has already some relation with school performance. In general, from the $2^{\text {nd }}$ grade onward, reading comprehension was more strongly related to academic performance than listening comprehension (in fact, there was no relation between school performance and listening comprehension in the partial correlation analysis for $2^{\text {nd }}$ and $3^{\text {rd }}$ grades). In these grade levels, good academic performance is related to good reading comprehension skills and use of alphabetic and orthographic strategies in recognizing words.

These findings are supported by the work of Tonelotto et al. (2005). In a sample of children aged 8 to 11 years, the authors noted that children with better school performances also performed better in reading words and non-words, but they had a higher detection rate and shorter reaction times in reading words than non-words. This suggests that the orthographic strategy may be more strongly related to academic performance than the alphabetical strategy.

Our partial correlations also supports that listening comprehension is an important ability since the very early stages of literacy (Florit \& Cain, 2011), besides word recognition (Aaron et al., 2008; Aaron et al., 1999; Oakhill et al., 2003), which seems to be the most related ability to school performance in 1 st graders. At the $2^{\text {nd }}$ 
Dias, N. M., Montiel, J. M. \& Seabra, A. G. (2015). Development and Interactions among Academic Performance, Word Recognition, Listening, and Reading Comprehension.

grade, children become more competent, and reading comprehension is the ability with most common variance with school performance, followed by word recognition. At the $3^{\text {rd }}$ grade, despite marginal significance of the data, a pattern similar of the $2^{\text {nd }}$ grade was found. Considering the $4^{\text {th }}$ grade, word recognition is better developed (Capovilla \& Dias, 2007; Diuk et al., 2009; Salles \& Parente, 2002) and does not contribute to the school performance variance. In fact, some authors have already proposed that the role of word-recognition skills to reading competence tends to decrease as children advance in school levels (Oakhill et al., 2003; Tilstra et al., 2009), and the same seems to happen in relation to school performance. In this level, reading comprehension becomes the ability most related with student's performance, followed by listening comprehension. In this sense, there was a trend to stronger relations between academic performance and more elementary abilities in initial grades, and with more complex skills developing during the last grades.

The change in the pattern of correlations is also consistent with the developmental data presented above and in previous studies (Capovilla \& Dias, 2007; Diuk et al., 2009; Florit \& Cain, 2011; Salles \& Parente, 2002). Accompanying the progressive development of strategies for word recognition, it is also consistent with results that reading comprehension has greater importance than listening comprehension in performance, which was observed from the $2^{\text {nd }}$ grade onward. This is because, along with listening comprehension, word recognition can be considered a prerequisite for reading comprehension, according to the SVR (Aaron et al., 2008; Aaron et al., 1999; Gough \& Tunmer, 1986).

Together, these findings may expand contributions to the field of designing interventions to minimize or prevent reading difficulties. Knowing the development of such skills in the early grades of elementary school, one can determine the best time to propose a specific program of instruction. For example, programs to expand listening, such as those that promote increased vocabulary, can be started very early in the $1^{\text {st }}$ grade. The $2^{\text {nd }}$ grade students will also benefit greatly from instruction that fosters reading comprehension. Similarly, students at the $1^{\text {st }}$ and $2^{\text {nd }}$ grades most likely achieve the most obvious gains using reading instruction that develops the alphabetical strategy, while children in higher grades, in which orthographic reading is consolidating, can benefit from the automation of this strategy.

This study shares the understanding that school performance can be influenced by several factors (Araújo, 2002). In addition to emotional factors (Dell'Aglio \& Hutz, 2004) or other aspects of cognitive domains (Boruchovitch, 1999; Capovilla \& Dias, 2008; Duncan et al., 2007), this research showed that comprehension and reading strategies for word recognition are related to school performance, confirming previous findings (Oliveira et al., 2008; Tonelotto et al., 2005). Supplementing those contributions, however, our research has shown that these relations are established differentially in the course of the $1^{\text {st }}$ to $4^{\text {th }}$ grade levels of elementary school.

\section{Final Considerations}

Despite all the measured skills being important components responsible for reading in all studied grade levels, the correlation of each skill with school performance changed with school progression: (a) revealing, as expected theoretically, the largest relation between logographic reading and school grades at the beginning of the scholarly process; (b) increasing importance of alphabetic and orthographic strategies in the $2^{\text {nd }}$ and $3^{\text {rd }}$ grades; and (c) highlighting greater relations between orthographic reading and school performance in the $4^{\text {th }}$ grade. Similarly, listening comprehension was more closely related to school performance in the $1^{\text {st }}$ grade, while in the following grades, this study found evidence for the increasing importance of reading comprehension.

The authors recognize the limitations of this study and point out some future investigations that could overcome such limitations and extend these data: (a) future studies should consider also the role of other factors (cognitive, emotional or social) that might affect school performance; (b) different measures, such as reading fluency/speed, should be considered in order to clarify their role in school performance; (c) measures of listening and reading comprehension that consider the comprehension of more complex paragraphs (rather than sentences) should also be considered.

The relation between reading skills and school performance reinforces the idea of competent reading's importance in knowledge acquisition and learning (as reflected in academic performance). This relevance to the different types of subject content acquisition, access to information and, by extension, effective integration into society (Lukasova, 2006), makes clear the importance of studies in this area that may contribute to understand the processes involved and their relations to academic achievement at different developmental levels. Some implications of this study for practice can include the consideration of developmental aspects in the comprehension of academic performance. Also, this knowledge can guide practices to stimulate and develop relevant skills in each school level, useful information for professionals who work directly with children in these developmental stages. Despite correlations between reading, comprehension, and academic performance are not something new, it is the first Brazilian and Latin-American study to investigate these relations from a developmental perspective. In this way, the authors hope this approach could be a trend in the area, helping to highlight the development of cognitive processes and how development can affect performance of our students. It could guide the understanding of the nature of learning difficulties or low academic performance in specific developmental stages, improving knowledge in developmental and educational psychology. 


\section{References}

Aaron, P. G., Joshi, R. M., Gooden, R., \& Bentum, K. E. (2008). Diagnosis and treatment of reading disabilities based on the component model of reading: An alternative to the discrepancy model of LD. Journal of Learning Disabilities, 41, 67-84. doi: $10.1177 / 0022219407310838$

Aaron, P. G., Joshi, R. M., \& Williams, K. A. (1999). Not all reading disabilities are alike. Journal of Learning Disabilities, 32, 120-137. doi:10.1177/002221949903200203

Araújo, A. (2002). Avaliação e manejo da criança com dificuldade escolar e distúrbio de atenção. Jornal de Pediatria, 78, S104S110. doi:10.1590/S0021-75572002000700013

Betjemann, R., Willcutt, E., Olson, R. K., Keenan, J. M., DeFries, J. C., \& Wadworth, S. J. (2008). Word reading and reading comprehension: Stability, overlap and independence. Reading and Writing, 21, 539-558. doi:10.1007/s11145-007-9076-8

Blatchford, P., Burke, J., Farquhar, C., Plewis, I., \& Tizard, B. (1985). Educational achievement in the infant school: The influence of ethnic origin, gender and home on entry skills. Educational Research, 27, 52-60. doi:10.1080/0013188850270108

Boruchovitch, E. (1999). Estratégias de aprendizagem e desempenho escolar: Considerações para a prática educacional. Psicologia: Reflexão e Crítica, 12, 361-376. doi:10.1590/ S0102-79721999000200008

Capovilla, A. G. S., \& Dias, N. M. (2007). Desenvolvimento de estratégias de leitura no ensino fundamental e correlação com nota escolar. Psicologia em Revista, 13, 363-382.

Capovilla, A. G. S., \& Dias, N. M. (2008). Desenvolvimento de habilidades atencionais em estudantes da $1^{\mathrm{a}}$ à $4^{\mathrm{a}}$ série do ensino fundamental e relação com rendimento escolar. $P s i$ copedagogia, 25, 198-211.

Capovilla, F. C., \& Seabra, A. G. (2013). Teste Contrastivo de Compreensão Auditiva e de Leitura. In A. G. Seabra, N. M. Dias, \& F. C. Capovilla (Eds.), Avaliação Neuropsicológica Cognitiva: Leitura, escrita e aritmética (Vol. 3, pp. 29-53). São Paulo, SP: Memnon.

Capellini, S. A., Tonelotto, J. M. F., \& Ciasca, S. M. (2004). Medidas de desempenho escolar: Avaliação formal e opinião de professores. Estudos de Psicologia (Campinas), 21, 79-90. doi:10.1590/S0103-166X2004000200006

Dell'Aglio, D. D., \& Hutz, C. S. (2004). Depressão e desempenho escolar em crianças e adolescentes institucionalizados. Psicologia: Reflexão e Crítica, 17, 351-357. doi:10.1590/ S0102-79722004000300008

Diuk, B., Borzone, A. M., Abchi, V. S., \& Ferroni, M. (2009). La adquisición de conocimiento ortográfico en niños de 1er a 3er año de educación básica. Psykhe, 18, 61-71. doi:10.4067/ S0718-22282009000100006

Duncan, G. J., Dowsett, C. J., Claessens, A., Magnuson, K., Huston, A., Klebanov, P., ...Japel, C. (2007). School readiness and later achievement. Developmental Psychology, 43, 1428-1446. doi:10.1037/0012-1649.43.6.1428

Florit, E., \& Cain, K. (2011). The simple view of reading: Is it valid for different types of alphabetic orthographies? Educational Psychology Review, 24, 553-576. doi:10.1007/ s10648-011-9175-6

Frith, U. (1985). Beneath the surface of developmental dyslexia. In K. Patterson, J. Marshall, \& M. Coltheart (Eds.), Surface Dyslexia: Neuropsychological and Cognitive Studies of Phonological Reading (pp. 301-330). London: Lawrence Erlbaum.
Frith, U. (1997). Brain, mind and behavior in dyslexia. In C. Hulme \& M. Snowling (Eds.), Dyslexia: Biology, cognition and intervention (pp. 1-19). London: Whurr.

Gois, A., \& Pinho, A. (2007). Brasil é reprovado, de novo, em matemática e leitura. Folha On-Line. Retrieved from http:/ www1.folha.uol.com.br/folha/educacao/ult305u351481.shtml

Gough, P., \& Tunmer, W. (1986). Decoding, reading and reading disability. Remedial and Special Education, 7, 6-10. doi:10.1177/074193258600700104

Holmes, M., \& Croll, P. (1989). Time spent on homework and academic achievement. Educational Research, 31, 36-45. doi:10.1080/0013188890310104

Kershaw, S., \& Schatschneider, C. (2010). A latent variable approach to the simple view of reading. Reading and Writing, 25(2), 433-464. doi:10.1007/s11145-010-9278-3

Lukasova, K. (2006). Alterações fonológicas e motoras na dislexia do desenvolvimento (Master's thesis, Universidade Presbiteriana Mackenzie, São Paulo, SP, Brazil). Retrieved from http://oatd.org/oatd/record?record=oai\%5C:mx.mackenzie.com.br\%5C: 171

Marmolejo-Ramos, F. (2007). Nuevos avances en el estudio científico de la comprensión de textos. Universitas Psychologica, 6(2), 331-343.

Ministério da Educação. (2005). Relatório Técnico do SAEB de 2003. Brasília, DF: Author. Retrieved from http://www.inep. gov.br/download/saeb/2003/Relatorio_Tecnico_Saeb_2003. pdf

Oakhill, J., Cain, K., \& Bryant, P. (2003). The dissociation of word reading and text comprehension: Evidence from component skills. Language and Cognitive processes, 18(4), 443-468. doi:10.1080/01690960344000008

Oliveira, J. B., \& Schwartzman, J. S. (2002). A escola vista por dentro. Belo Horizonte, MG: Alfa Educativa.

Oliveira, K. L., Boruchovitch, E., \& Santos, A. A. A. (2008). Leitura e desempenho escolar em português e matemática no ensino fundamental. Paidéia (Ribeirão Preto), 18, 531-540. doi:10.1590/S0103-863X2008000300009

Organisation for Economic Cooperation and Development. (2010). PISA 2009 Results: Executive summary. Retrieved from http://www.oecd.org/pisa/pisaproducts/46619703.pdf

Pastura, G. M. C., Mattos, P., \& Araújo, A. P. Q. C. (2005). Desempenho escolar e transtorno do déficit de atenção e hiperatividade. Revista de Psiquiatria Clínica, 32, 324-329. doi:10.1590/S0101-60832005000600003

Salles, J. F., \& Parente, M. A. M. P. (2002). Processos cognitivos na leitura de palavras em crianças: Relações com compreensão e tempo de leitura. Psicologia: Reflexão e Crítica, 15, 321331. doi:10.1590/S0102-79722002000200010

Seabra, A. G., \& Capovilla, F. C. (2010). Teste de Competência de Leitura de Palavras e Pseudopalavras. São Paulo, SP: Memnon.

Seabra, A. G., \& Dias, N. M. (2012). Reconhecimento de palavras e compreensão de leitura: Dissociação e habilidades linguístico-mnemônicas preditoras. Neuropsicologia Latinoamericana, 4(1), 43-56. doi:10.5579/rnl.2012.0101

Seabra, A. G., Dias, N. M., \& Capovilla, F. C. (Eds.). (2013). Avaliação Neuropsicológica Cognitiva: Leitura, escrita e aritmética: Vol. 3. São Paulo, SP: Memnon.

Suehiro, A. C. B. (2008). Processos fonológicos e perceptuais e aprendizagem da leitura e escrita: Instrumentos de avaliação (Doctoral dissertation, Universidade São Francisco, Bragança Paulista, SP, Brazil). Retrieved from http://www.dominiopublico.gov.br/download/texto/cp083990.pdf 
Dias, N. M., Montiel, J. M. \& Seabra, A. G. (2015). Development and Interactions among Academic Performance, Word Recognition, Listening, and Reading Comprehension.

Tilstra, J., McMaster, K., Van den Broek, P., Kendeou, P., \& Rapp, D. (2009). Simple but complex: Components of the simple view of reading across grade levels. Journal of Research in Reading 32(4), 383-401. doi:10.1111/j.14679817.2009.01401.x

Tonelotto, J. M. F., Fonseca, L., Tedrus, G., Martins, S., Gibert, M., Antunes, T., \& Pensa, N. (2005). Avaliação do desempenho escolar e habilidades básicas de leitura em escolares do ensino fundamental. Avaliação Psicológica, 4, 33-43.

Valenzuela, J. (2008). Características psicométricas de una escala para caracterizar el sentido del aprendizaje escolar. Univesitas Psychologica, 8(1), 49-60. 